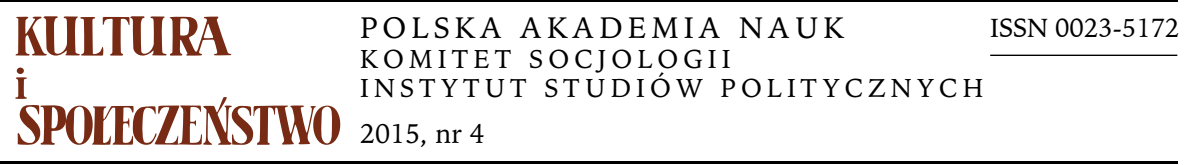

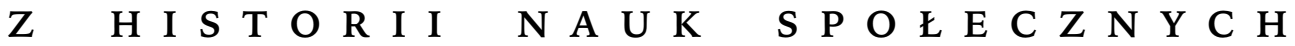

AGATA ZYSIAK

Uniwersytet Łódzki

\section{NIEPOKORNA NAUKA I ROBOTNICZE MIASTO SIEDEMDZIESIĘCIOLECIE SOCJOLOGII NA UNIWERSYTECIE ŁÓDZKIM}

Rok 2015 obfitował w rocznice związane z końcem drugiej wojny światowej, a w przypadku Łodzi wiązały się one $z$ odradzaniem się miasta po wojnie, w tym przede wszystkim z powstaniem łódzkiego życia naukowego. Wiosną tego roku zorganizowano serię wydarzeń dla uczczenia siedemdziesięciolecia działalności Uniwersytetu Łódzkiego, we wrześniu pięćdziesięciolecia Wydziału Ekonomiczno-Socjologicznego, a w piątek 13 listopada 2015 r. odbył się jubileusz łódzkiej socjologii - starszej od tego macierzystego wydziału o dwadzieścia lat.

Kiedy w 1944 roku Józef Obrębski, Stanisław Ossowski i Józef Chałasiński jechali do Lublina, negocjować z nowymi władzami odbudowę polskiej socjologii, zapewne nie sądzili, że będzie się to działo w Łodzi. To tu właśnie w 1945 roku odradzało się kulturalne i naukowe życie kraju - 120 kilometrów od zniszczonej Warszawy istniało nie zburzone, ale opuszczone miasto, przed rozpoczęciem wojny drugie co do wielkości miasto II RP. Kiedy socjologowie przybyli na miejsce, wiele już zrobiono dla utworzenia wyższej uczelni w robotniczym mieście, a Chałasiński miał odegrać w jej początkach znaczną rolę. Już z Łodzi tak w 1945 roku pisał do Floriana Znanieckiego:

„Po tych wszystkich przejściach niektórzy z nas dostali choroby zagranicznej [...]. Inni, i do tych ja należę, dostali choroby innej - tylko tutaj w Polsce, tylko na tych gruzach, zapracować się na śmierć, ale odbudować wszystko. Te dwie kategorie chorych ludzi nie bardzo rozumieją się wzajemnie" ${ }^{1}$.

Adres do korespondencji: agatazysiak@gmail.com s. 35 .

${ }^{1}$ Zygmunt Dulczewski, Florian Znaniecki: życie i dzieło, Wydawnictwo Poznańskie, Poznań 1984, 
Warto przypomnieć, że w Polsce pierwsza katedra socjologii powstała na Wydziale Prawa Uniwersytetu Warszawskiego w 1919 roku. Rok później, z inicjatywy Floriana Znanieckiego, uruchomiono Katedrę Socjologii i Filozofii Kultury na Uniwersytecie Poznańskim, wtedy też socjologia zaistniała w Polsce jako samodzielny kierunek studiów. Na Uniwersytecie Jagiellońskim zajęcia $\mathrm{z}$ socjologii pojawiły się $\mathrm{w}$ drugiej połowie lat dwudziestych. W Wolnej Wszechnicy Polskiej od pierwszych lat powojennych elementy socjologii wykładali Ludwik Krzywicki i Leon Petrażycki. W 1936 roku Władysław Grabski stworzył w Szkole Głównej Gospodarstwa Wiejskiego Zakład Socjologii Wsi. Po drugiej wojnie światowej dalece nie wszystkim przedstawicielom pokolenia założycieli socjologii $\mathrm{w}$ Polsce było dane brać udział w odbudowie dyscypliny - wielu zginęło, część przebywała za granicą i miała już nie wrócić do kraju.

Socjologia, jak wspomniałam, zaczynała się odradzać w Łodzi. W kwietniu 1945 roku zostały utworzone dwie katedry socjologiczne: Katedra Socjologii — pod kierownictwem Józefa Chałasińskiego, w której pracę rozpoczął także dr Jan Szczepański, oraz Katedra Socjologii Szczegółowej — pod kierownictwem Józefa Obrębskiego. W maju zorganizowano trzecią katedrę socjologiczną - Katedrę Teorii Kultury, którą objął Stanisław Ossowski. Powstał w ten sposób najsilniejszy ośrodek socjologiczny w kraju ${ }^{2}$. Trzeba pamiętać, że w roku akademickim 1945/1946 Uniwersytet Łódzki był drugim — po Krakowie - największym uniwersytetem, na który składały się 132 katedry, 530 pracowników (w tym 173 profesorów i zastępców, 498 pomocniczej kadry i 207 personelu administracyjno-gospodarczego), uczyło się w nim ponad 7000 studentów, co stanowiło $27 \%$ wszystkich studiujących w Polsce ${ }^{3}$.

$\mathrm{W}$ Łodzi dynamicznie rozwijało się życie naukowe. Rosło w siłę środowisko „Kuźnicy”, „Myśli Współczesnej”, a także „Wsi” i wielu innych tytułów, pracę rozpoczynały teatry, zakładano przedszkola, szkoły, uczelnie - a zarazem strajkowali robotnicy i ogromne rzesze przybyszów napływały do miasta. Kultura wysoka ścierała się z kulturą masową. Co istotne z perspektywy historii UŁ, środowisko naukowe w kraju oprotestowało tworzenie nowych ośrodków naukowych, uzasadniając to stanowisko brakami środków i sił fachowych. Dodatkowo UŁ mógł być uważany za „kopciuszka, traktowanego z góry przez inne uniwersytety", ze względu na brak tradycji, postać lewicowego rektora Tadeusza Kotarbińskiego, a także ze względu na pomysły, aby do Łodzi przenieść Uniwersytet Warszawski, co nie mogło cieszyć się sympatią środowiska.

2 Czesław Gryko, Józef Chałasiński - człowiek i dzieło. Od teorii wychowania do kulturowej wizji narodu, Wydawnictwo Wyższej Szkoły Przedsiębiorczości i Administracji, Lublin 2007, s. 23.

${ }^{3}$ Bohdan Baranowski, Krzysztof Baranowski, Pierwsze lata Uniwersytetu Łódzkiego, 1945-1949, Wydawnictwa Uniwersytetu Łódzkiego, Łódź 1985, s. 79; Jan Nosko, Rewolucja $i$ inteligencja: PPR i PZPR $w$ tódzkim środowisku akademickim 1945-1971, Wydawnictwo Łódzkie, Łódź 1985, s. 39. 
Wkrótce Uniwersytet Łódzki zaczął być nazywany „czerwonym uniwersytetem”, a Łódź stała się „magnesem dla lewicowych intelektualistów” ${ }^{4}$. Co ciekawe - zbyt radykalne głosy, jak te Stefana Żółkiewskiego czy Adama Schaffa, nawołujące do rewolucji i gwałtownych zmian, były w owym czasie odrzucane przez główny nurt PPR, a nawet uważane za szkodliwe. Jan Szczepański zanotował w listopadzie 1945 roku: „Wprawdzie trudno zaprzeczyć niesłychanemu prymitywizmowi politycznemu ludzi z Lublina, ale ich program powinien być programem jutra" ${ }^{5}$. Podczas uroczystej inauguracji roku akademickiego w styczniu 1946 roku ówczesny wiceminister oświaty Władysław Bieńkowski, socjolog, mówił:

„Otwarcie Uniwersytetu Łódzkiego ma znaczenie symbolu. Łódź, miasto wielkie, dziś, po zburzeniu stolicy, największe w Polsce, nie mogła do r. 1939 uzyskać pełnej, normalnej szkoły akademickiej. [...] Dzień dzisiejszy, dzień inauguracji Uniwersytetu Łódzkiego, symbolizuje akt dziejowy społecznej sprawiedliwości, symbolizuje dążenie polskiej Demokracji do otwarcia bram szkół wyższych dla szerokich mas pracujących, symbolizuje zbliżenie wiedzy z pracą, symbolizuje współpracę robotnika przy warsztacie i naukowca na katedrze czy w laboratorium" 6 .

Drugim silnym socjologicznym ośrodkiem w owych czasach stał się Uniwersytet Warszawski (nabór na socjologię od 1947), w którym kierownikiem Katedry Socjologii został Jan Stanisław Bystroń, a wykłady miał Ossowski. Studia socjologiczne reaktywowano w Uniwersytecie Poznańskim, licząc na powrót do Polski Znanieckiego. Gdy nie zdecydował się on na powrót, socjologią kierował jego uczeń, Tadeusz Szczurkiewicz, który od 1946 roku objął też Katedrę Socjologii na Uniwersytecie Mikołaja Kopernika w Toruniu (zlikwidowana w 1950). Socjologia wykładana była również w Uniwersytecie Jagiellońskim oraz w Katolickim Uniwersytecie Lubelskim, gdzie pracował ks. Franciszek Mirek, uczeń Znanieckiego. Uniwersytet Wrocławski borykał się z trudnościami w znalezieniu kadry profesorskiej.

Rozwój uniwersytetu i socjologii w Łodzi opóźnił dekret z 28 października 1947 r. „O organizacji nauki i szkolnictwa wyższego”, który zastąpił przywróconą po wojnie ustawę z roku 1933. Poważnie ograniczał on autonomię uczelni, wprowadzając czynny udział władz centralnych w polityce personalnej, przyznawaniu habilitacji, obsadzie rektorów. Rządowa reforma nauki czyniła z uniwersytetów narzędzia planu sześcioletniego — jak wszystkie elementy

\footnotetext{
${ }^{4}$ John Connelly, Zniewolony uniwersytet. Sowietyzacja szkolnictwa wyższego w Niemczech Wschodnich, Czechach i Polsce 1945-1956, tłum. Witold Rodkiewicz, Instytut Historii Nauki PAN-Aspra-JR, Warszawa 2014.

5 Jan Szczepański, Dzienniki z lat 1945-1968, Galeria „Na Gojach”, Ustroń 2013, s. 20.

6 „Przemówienie p. Wiceministra Władysława Bieńkowskiego na uroczystej inauguracji roku akademickiego na Uniwersytecie Łódzkim dnia 13 stycznia 1946 r.", Archiwum Uniwersytetu Łódzkiego, Biuro Rektora 1946, nr sygn. 1856.
} 
gospodarki i społeczeństwa miały prowadzić „przez industrializację ku socjalizmowi". Jednocześnie nastąpił wyjazd ludzi z Łodzi, w tym socjologów (jak Maria i Stanisław Ossowscy, Nina Assorodobraj). Od końca 1948 roku, wraz z postępem odbudowy Warszawy, Łódź doświadczyła gwałtownego odpływu dawnych mieszkańców stolicy. Wkrótce na uczelniach wprowadzono limity rekrutacji, corocznie określane przez ministerstwo, zmniejszono liczbę kierunków. UŁ stracił uprzywilejowaną pozycję i został zaklasyfikowany do tzw. małych uniwersytetów, mógł prowadzić tylko podstawowe kierunki: prawo, biologię, geografię, matematykę, fizykę, chemię, historię i polonistykę. Wszystkie wysoko specjalistyczne kierunki mogły działać tylko na Uniwersytecie Warszawskim. Nabór na socjologię zlikwidowano. Nie był to jednak koniec łódzkiego ośrodka, ale raczej początek mitu fundacyjnego dla kolejnych pokoleń socjologów - mitu niepokornej socjologii, trwającej mimo przeciwności i zachowującej wysoki poziom badań oraz żywe środowisko naukowe.

Właśnie teza o „niepokornej socjologii” otworzyła obchody siedemdziesięciolecia łódzkiej socjologii, kiedy profesor Kaja Kaźmierska, dyrektor Instytutu Socjologii, witając gości przypomniała, iż od początku socjologia w Łodzi sprawiała trudności władzom. Zaklasyfikowana jako „nauka burżuazyjna”, już pod koniec lat czterdziestych funkcjonowała na marginesach oficjalnego życia akademii. Socjologowie odegrali ważną rolę dopiero w debatach podczas tzw. odwilży, w procesie poznańskim po 1956 roku czy strajku studentów w 1981 roku. Losy dyscypliny stały się w sposób oczywisty głównym tematem jubileuszu. Wydarzenie składało się $z$ dwóch części: panelu dyskusyjnego pt. „Socjologia łódzka na przestrzeni dekad - refleksja nad przeszłością i współczesnością” oraz części poświęconej historii uczelni pt. „Socjologia łódzka - historia i wspomnienia". Pierwsza część spotkania miała charakter indywidualnych wypowiedzi dwóch pokoleń badaczy, nestorów dyscypliny: profesorów Krystyny Lutyńskiej, Jolanty Kulpińskiej, Zbigniewa Bokszańskiego oraz przedstawicieli młodszego pokolenia pracowników naukowych: Wojciecha Woźniaka, Magdaleny Nowickiej oraz Jakuba Niedbalskiego.

Jolanta Kulpińska i Krystyna Lutyńska szczegółowo przypomniały słuchaczom najważniejsze fakty, nazwiska i perypetia łódzkich socjologów na przestrzeni siedemdziesięciu lat. Lutyńska przedstawiła trzy aspekty mające wpływ na rozwój socjologii w Łodzi i rangę tego ośrodka. Były to: wysoki poziom pierwszego pokolenia socjologów, jakość badań na międzynarodowym poziomie (przede wszystkim łódzkiej szkoły metodologicznej) oraz działalność łódzkiego oddziału Polskiego Towarzystwa Socjologicznego.

Profesor wskazała na „dobry start” łódzkiej socjologii, kiedy do miasta w roku 1945 ściągnęli najwybitniejsi uczniowie Floriana Znanieckiego — Józef Chałasiński, Tadeusz Szczurkiewicz i Jan Szczepański. Chałasiński stał się naturalnym spadkobiercą Znanieckiego, a Łódź przejęła rolę Poznania jako głównego ośrodka socjologicznego. W pierwszych latach powojennych na socjologii wykładali także Stanisław i Maria Ossowscy, Witold Kula, Nina Assorodobraj, 
asystentami na socjologii byli Antonina Kłoskowska, Jan Lutyński i Wacław Piotrowski. Profesor Lutyńska przywołała postać Józefa Chałasińskiego, uczonego pragnącego budować uniwersytet otwarty dla klas pracujących — najpierw wytykano mu komunizm, potem, gdy krytykował PZPR, wolty ideologiczne. Z perspektywy Warszawy przezywano łódzką socjologię „chałasińszczyzną”, co nie ułatwiało relacji ze stolicą.

Profesor zwróciła uwagę na rolę biblioteki socjologicznej, księgozbioru otworzonego zaraz po drugiej wojnie światowej, który niebawem miał stać się drugą największą tego typu kolekcją książek socjologicznych w kraju. Biblioteka posiadała rzadkie pozycje, prace autorów zagranicznych (wkrótce stały się one w Polsce niedostępne), książki naznaczone przez wojnę, a przede wszystkim okazała się ważną przestrzenią spotkań i integracji łódzkich socjologów. Następnie Lutyńska mówiła o trudnych losach „niepokornej” socjologii w latach pięćdziesiątych oraz o jej późniejszej instytucjonalnej odbudowie. Zwiastując początki odwilży, łódzcy socjologowie już w 1955 roku ogłosili konkurs na pamiętniki inteligencji, jednak mimo pozytywnego odzewu i wielu nadesłanych prac rezultatów badania nigdy nie opublikowano ze względu na cenzurę, a zebrane wówczas materiały zaginęły. Wreszcie w roku 1956 przywrócono nazwy katedr, a od 1957 socjologia znów stała się kierunkiem akademickim. Przywrócono do pracy wykładowców, którzy utracili swe stanowiska. W drugiej połowie lat pięćdziesiątych przeprowadzono szeroko zakrojone badania na temat szkolnictwa wyższego, prowadzone pod kierownictwem Jana Szczepańskiego na Uniwersytecie Łódzkim i w Zakładzie Badań Socjologicznych PAN, dotyczyły one absolwentów szkół średnich, kursu przygotowawczego oraz studiów wyższych. W latach 1956-1968 socjologię można było studiować w Warszawie, Łodzi, Lublinie, Krakowie i Poznaniu (od 1968). Działał utworzony w 1958 roku Ośrodek Badania Opinii Publicznej.

Po tym wystąpieniu profesor Kulpińska nie miała łatwego zadania i aby uniknąć powtórzeń, skupiła się przede wszystkim na przeglądzie osiągnięć łódzkiej socjologii — od trudów z kontynuowaniem prac „nauki burżuazyjnej” w czasie stalinizmu, poprzez lepszy czas odwilży po 1956 roku oraz późniejsze problemy $z$ lat sześćdziesiątych, kiedy odsunięto od życia akademickiego Józefa Chałasińskiego i przeniesiono socjologię z Wydziału Humanistycznego na Wydział Ekonomiczny (dopiero po trzech latach przemianowany na Ekonomiczno-Socjologiczny). Przypomniała także lata siedemdziesiąte, kiedy po odgórnych zmianach struktur wydziałów i rozdrobnieniu socjologii na oddzielne katedry nadal nieformalnie zachowano dawną strukturę, a łódzcy socjologowie przechowali poczucie wspólnoty. Wiele miejsca Kulpińska poświęciła także losom "Przeglądu Socjologicznego", najstarszego polskiego czasopisma socjologicznego, założonego w 1930 roku przez Floriana Znanieckiego w Poznaniu, a po wojnie wydawanego w Łodzi pod redakcją Józefa Chałasińskiego. Gdy socjologia $\mathrm{w}$ Łodzi została zlikwidowana $\mathrm{w}$ okresie stalinizacji, także wydawanie „Przeglądu” zawieszono i po ukazaniu się trzech numerów powojennych na 
kolejny trzeba było czekać aż do 1956 roku. Wtedy także zaczęły się pojawiać inne czasopisma socjologiczne: „Kultura i Społeczeństwo” oraz „Studia Socjologiczne”. Po śmierci Chałasińskiego „Przegląd” redagował Jan Lutyński, a następnie po dziś dzień Jolanta Kulpińska.

Profesor Bokszański przedstawił słuchaczom perspektywę studenta rozpoczynającego studia w 1959 roku. Przypomniał, że wówczas życie łódzkiej socjologii koncentrowało się przy ulicy Uniwersyteckiej 3, gdzie mieściły się sale seminaryjne, siedziby katedr, biblioteka socjologiczna, a przez ścianę profesorskie mieszkania. Historia socjologii w tej kamienicy sięgała 1945 roku, kiedy ze względu na trudne warunki lokalowe wielu filozofów, socjologów czy pedagogów (choć nie tylko) zamieszkało w jednym miejscu. Przestrzeń prywatna i oficjalna przenikały się, tworząc tym samym warunki do nieustającej dyskusji. Profesor zażartował, że była to niemal „społeczność wioskowa”, cechująca się zarówno silnymi więziami, jak i brakiem prywatności. Podkreślił także rolę mistrza i wyjątkową atmosferę studiowania. Wysokie wymagania stawiane przez ówczesnych profesorów, poważanie wobec książek i ciężka praca charakteryzowały studenckie życie. Bokszański odniósł się także do kondycji socjologii w latach sześćdziesiątych, wspomnianych przez przedmówczynię. Obok ówczesnych trudności pojawiły się wówczas nowe możliwości wyjazdów zagranicznych, do Łodzi skierowano tak wybitnych badaczy jak Włodzimierz Wesołowski czy Maria Hirszowicz. Choć w planie władz mieli oni stanowić kontrapunkt dla „niepokornej” łódzkiej socjologii, to w rezultacie wzmocnili ośrodek i rozpoczęli wiele wartościowych projektów badawczych.

W dalszej części spotkania głos zabrało młodsze pokolenie. Wojciech Woźniak wskazał najważniejsze aspekty łączące pokolenia socjologów, czyli ciągłość zainteresowań i metod oraz międzynarodowe powiązania. Dla tego pierwszego elementu kluczowy jest, jego zdaniem, lokalny kontekst — to znaczy robotnicze miasto Łódź, będące ogromnym laboratorium społecznym. Wiele socjologicznych badań wynikało bezpośrednio z umiejscowienia ośrodka, tak było w przypadku badań klasy robotniczej, pierwszych pokoleń absolwentów, socjologii przemysłu, a po '89 także biedy i wykluczenia. Woźniak zwrócił uwagę także na pozaakademickie konsekwencje obecności tak silnego ośrodka socjologicznego w deindustrializującym się mieście, wymieniając absolwentów socjologii, którzy pełnili i pełnią ważne role w lokalnych instytucjach i działają na rzecz miasta. Drugi aspekt łączący pokolenia to współpraca międzynarodowa, której ciągłość, przede wszystkim w przypadku fińskiego Tampere i niemieckiego Gissen, może zadziwiać. Jednocześnie to właśnie ten aspekt jest kluczowy dla wykroczenia poza lokalny kontekst i pozwala spojrzeć na takie miasto jak Łódź $z$ globalnej perspektywy.

Magdalena Nowicka przedstawiła krytyczny manifest na temat roli socjologii we współczesnym społeczeństwie. Wyzwaniem stającym przed łódzkimi badaczami jest zajęcie miejsca w globalnym świecie nauki, a co za tym idzie sproblematyzowanie własnego kontekstu: naukowców z Europy Wschodniej, 
którzy nawet jeśli jeżdżą coraz częściej po świecie, to uwięzieni są w rolach tłumaczy czy regionalnych „ciekawostek”. Jest to tylko jedno z zagadnień, z którymi musi zmierzyć się współczesna socjologia łódzka, a także polska. Zmiany w sferze publicznej przyniosły niepokojące procesy, jak instrumentalizacja roli socjologów w dyskursie publicznym - utracili oni wpływ na kształtowanie świata, stając się jedynie narzędziem polityków i mediów. Innym problemem, wynikającym $z$ niedawnej reformy nauki, jest jej centralizacja, to znaczy spadek znaczenia na akademickiej mapie kraju lokalnych ośrodków badawczych poza Warszawą - regionalne uczelnie kształtujące sferę publiczną na lokalnym poziomie i zapewniające dostęp do wyższego wykształcenia tracą możliwości rozwoju, a nawet funkcjonowania. Niepokojącym procesem w nauce jest także postępująca indywidualizacja badań i utrata więzi we wspólnocie akademickiej: brak komunikacji między badaczami i dyskusji niezbędnej do tworzenia nauki. Jednocześnie obecna zmiana pokoleniowa i radykalizacja nastrojów politycznych konfrontuje socjologów z koniecznością przypomnienia i obrony kanonu wartości uniwersalnych. Jak diagnozowała panelistka, nastąpił rozdźwięk między pokoleniami studentów i wykładowców, widoczny choćby przy okazji dyskusji o pomocy uchodźcom. Wystąpienie zakończyło wezwanie do działania i zerwania z "przezroczystą" socjologią. Biorąc pod uwagę poprzednie głosy, był to apel o socjologię „niepokorną". Powinna ona głosić wyraziste poglądy, tworzyć kontrdyskursy wobec dominujących przekazów, musi zjednoczyć się, protestować, działać jako środowisko broniące etosu nauki.

Ostatnie wystąpienie, Jakuba Niedbalskiego, było próbą oceny kondycji współczesnej socjologii w Łodzi, nieco żartobliwie ujętą w ramy analizy SWOT. Zgodnie $z$ wybraną metodą zostały omówione mocne i słabe strony ośrodka oraz szanse i zagrożenia stojące w przyszłości na drodze rozwoju łódzkiej socjologii. Zdaniem autora do mocnych stron należy tradycja ośrodka, wspierająca jego obecne działania, ale także szeroki przekrój pokoleniowy pracowników, rozwój metod badawczych, w tym zarówno jakościowych, jak i ilościowych. $Z$ kolei słabe strony łódzkiej socjologii to ograniczona wymiana doświadczeń i wiedzy wewnątrz instytutu oraz stosunkowo niewielka współpraca naukowo-badawcza z innymi jednostkami. Różnorodność stosowanych paradygmatów i metod badawczych nie przekłada się na jakość dyskusji. Za to ma, niestety, przełożenie na trudności w prowadzeniu spójnej polityki rozwojowej czy nawet wypracowaniu wspólnego stanowiska w kwestiach organizacyjnych. Następnie Niedbalski omówił szanse łódzkiego ośrodka, czyli przede wszystkim możliwość zajęcia wysokiej pozycji w polskiej nauce i aktywnego kształtowania zarówno oblicza nauk społecznych, jak i sfery publicznej w kraju. Szanse te są ograniczone przez konkurencję innych ośrodków oraz brak zainteresowania socjologią ze strony studentów i biznesu czy osób spoza akademii w ogólności.

Druga część rozpoczęła się wystąpieniem pt. „Początki socjologii, początki uniwersytetu”. Obecne już wcześniej wątki dotyczące postaci Józefa Chałasińskiego i początków Uniwersytetu Łódzkiego zostały omówione przez 
Agatę Zysiak. Przypomniano historyczny kontekst powstania UŁ, utworzonego w kontrze do międzywojennych tradycji polskiej akademii, oraz projekt budowy uniwersytetu socjalistycznego, w którym aktywną rolę odegrał wspominany już uczeń Znanieckiego - profesor Chałasiński, który chciał otworzyć szkolnictwo wyższe na młodzież pochodzącą z klas pracujących.

W tej części pokazano także archiwalne zdjęcia z życia łódzkiej socjologii, nie zabrakło kadrów zarówno $z$ lat pięćdziesiątych, jak i dziewięćdziesiątych. Wśród zdumiewających niekiedy obrazów można było zauważyć na przykład: Józefa Chałasińskiego, Jana Szczepańskiego i Krystynę Lutyńską jedzących „kapitalistyczne krewetki" na pamiętnym kongresie socjologicznym w Stresie ${ }^{7}$ czy Jana Lutyńskiego grającego w ping-ponga i kibicującą Antoninę Kłoskowską.

Ukoronowaniem spotkania była projekcja filmu dokumentalnego pt. „Socjologia łódzka”, który został przygotowany specjalnie na jubileusz na podstawie materiałów archiwalnych Józefa M. Kononowicza. Unikalne kadry zostały zarejestrowane na początku lat sześćdziesiątych, kiedy córka tego łódzkiego poety, Grażyna Kononowicz (późniejsza wieloletnia kierownik Biblioteki Socjologicznej im. Józefa Chałasińskiego), rozpoczynała studia socjologiczne. Obecnie, $z$ kilku godzin tego surowego materiału powstał kilkunastominutowy film zrealizowany przez absolwenta łódzkiej socjologii Adama Musiałowicza, którego bohaterami - poza Grażyną Kononowicz i studentami z jej rocznika — są Jan Szczepański, Józef Chałasiński i Antonina Kłoskowska.

Choć Uniwersytet Łódzki wciąż może uchodzić za stosunkowo młodą uczelnię, to socjologia łódzka ze względu na jej historię i kontekst powstania pozostaje jednym z najważniejszych ośrodków nauk społecznych w kraju. W obecnej sytuacji politycznej i wobec narastających trudności, między innymi spadku znaczenia ośrodków lokalnych, socjologia nadal powinna pozostać „niepokorna" - tak jak w przeszłości, kiedy zachowywała niezależność myślenia, broniła uniwersaliów, jak wolność czy demokracja, wreszcie dbała o wysoką jakość badań bez względu na okoliczności i naciski otoczenia. To już nie od tradycji, ale od obecnego pokolenia naukowców zależy jej przyszłość.

\footnotetext{
7 To właśnie na IV Światowym Kongresie Socjologii w Mediolanie i Stresie we wrześniu 1959 roku Chałasiński wystąpił z referatem pt. „Sociology and Social Mythology in Post-war Poland". Analizował wpływ mitu socjalistycznego na polskich socjologów. Większość z nich, w tym sam autor, popierała socjalizm. Dla głębszej oceny ustroju kluczowe pozostawały — jak podkreślił Chałasiński - kwestie jego charakterystyki oraz metod wprowadzania, co odczytano jako krytykę „polskiej drogi do socjalizmu”. W kraju referat został potraktowany jako paszkwil, a Chałasiński utracił obejmowane stanowiska. Od 1961 roku został odsunięty także od zajęć na Uniwersytecie Łódzkim, gdzie wciąż był zatrudniony mimo wcześniejszego wyjazdu do Warszawy.
} 